\title{
MEMBUAT PETA PIKIRAN PADA KEGIATAN PRABACA UNTUK MENGIDENTIFIKASI IDE POKOK DAN MENYIMPULKAN ISI TEKS BERITA MELALUI COLLABORATIVE ACTION RESEARCH
}

\author{
${ }^{1}$ Sumarwati \& ${ }^{2}$ Siti Martabatul \\ ${ }^{1}$ Universitas Sebelas Maret \\ ${ }^{2}$ SMP Negeri 8 Surakarta \\ Surel:watik_uns@ymail.com; sitimartabatul@yahoo.co.id
}

\begin{abstract}
Abstrak: Salah satu hambatan dalam pengembangan kemampuan membaca pada siswa adalah tidak terlatihnya mereka dalam melakukan aktivitas membaca dengan tujuan tertentu. Oleh karenanya, siswa membaca dengan memberi porsi perhatian yang sama pada seluruh bagian bacaan. Pembelajaran ini bertujuan untuk meningkatkan kemampuan memahami bacaan melalui pembuatan peta pikiran. Penelitian ini adalah penelitian tindakan kelas yang dilakukan dalam tiga siklus. Partisipan adalah siswa dan guru kelas 8D SMP Negeri 8 Surakarta. Hasilnya menunjukkan bahwa ada peningkatan kemampuan mengidentifikasi ide pokok melalui penyusunan peta pikiran dan kemampuan membuat simpulan berita. Prosedur pembelajaran yang efektif adalah sebagai berikut. Para siswa diberti teks berita, mengidentifikasi ide pokok yang relevan dengan kata-kata pertanyaan $5 \mathrm{~W}+1 \mathrm{H}$, memformulasikan ide pokok ke dalam peta pikiran, mengingat ide pokok pada peta pikiran, membaca teks berita secara intensif untuk mereview ide pokok yang termuat dalam teks berita, menyatakan simpulan berdasarkan ide pokok pada peta pikiran, dan menjawab pertanyaan (mengikuti tes). Kesimpulan penelitian ini adalah bahwa ide-ide pokok yang diidentifikasi pada kegiatan prabaca untuk dikembangkan menjadi pita pikiran, tidak hanya memungkinkan dilakukannya kegiatan membaca denga tujuan tertentu, tetapi juga membantu siswa dalam memfokuskan perhatian pada bagian-bagian teks.
\end{abstract}

Kata Kunci: peta pikiran, membaca intensif, memahami bacaan, tujuan membaca

\section{MAKE THOUGHTS MAPPING ON THE PRE LITERATURE ACTIVITIES TO IDENTIFY THE IDEAS AND CONCLUSION OF THE TEXT CONTENTS NEWS THROUGH COLLABORATIVE ACTION RESEARCH}

\begin{abstract}
One of the obstacles in developing reading skills in students is that they are not trained in reading activities for specific purposes. Therefore, students read by giving equal attention to all parts of the reading. Thi study aims to improve the reading ability through thue use of mind mapping. This study was an classroom action research and conducted in three cycles. The participants were students class $8 D$ and Indonesian Language teacher of SMP Negeri 8 Surakarta. The result showed that there was an improvement in the percentace of formulating the mind map, reading activity and ability. The effective learning procedure was as follows. The students surveyed the text, identified the main idea of the text with questions word $5 \mathrm{~W}+1 \mathrm{H}$, formulated mind map, memorized the main idea of mind map, read the text intensively that they could use their maps as a review of information gained, stated the conclusion about ideas in the mind map, and answered the questions (take a test. The conclusion of this study is that the main ideas identified in the pre-reading activities to be developed into a mind band, not only allows the reading activities with a specific purpose, but also helps students to focus attention on the parts of the text.
\end{abstract}

Keywords: mind maps, intensive reading, reading comprehension, purpose of reading

BASASTRA Jurnal Bahasa, Sastra, dan Pengajarannya

Volume 7 Nomor 1, April 2019, ISSN I2302-6405 


\section{PENDAHULUAN}

Sebagaimana hasil pengukuran yang dilakukan oleh PISA atau Programme for International Student Assestment tahun 2016, yakni suatu survei terhadap literasi membaca, matematika, dan sain pada siswa usia SMP dari berbagai negara, menunjukkan kemampuan literasi membaca siswa Indonesia ada di urutan 61 dari 65 negara (KOMPAS, 12 Desember 2016). Ini merupakan posisi terendah untuk negara-negara di kawasan Asia Tenggara. Rendahnya kemampuan para siswa menjadi petunjuk adanya kelemahan sekaligus kesulitan belajar, yang dalam hal ini berarti ada kelemahan dan kesulitan belajar membaca. Hal itu terjadi terutama pada aktivitas membaca intensif. Membaca intensif adalah kegiatan membaca tak bersuara dengan tujuan utama untuk memahami isi tekc tertulis secara mendalam dan menyeluruh.

Permasalahan yang sama juga selalu terjadi pada siswa kelas 8 SMP Negeri 8 Surakarta. Adapun siswa kelas 8 yang diidentifikasi guru mengalami masalah dalam pembelajaran membaca adalah siswa kelas 8D (dibandingkan lima kelas pararel lainnya). Setidaknya hal ini tampak dari hasil tes membaca yang menunjukkan bahwa hanya $70 \%$ siswa yang memiliki kemampuan memadai (mencapai nilai minimal 75). Berdasarkan hasil wawancara dengan guru Bahasa Indonesia diperoleh informasi bahwa kesulitan membaca pemahaman pada siswa bersumber pada kesulitan memahami pikiran utama atau ide pokok dalam bacaan, selain rendahnya minat dan motivasi mereka dalam belajar membaca. Dari pengamatan guru diperoleh informasi mengenai penyebab siswa sulit memahami isi sebuah bacaan, yakni mereka kurang mampu menyeleksi bagianbagian yang penting dan kurang penting. Oleh karena itu, mereka memberikan porsi perhatian yang sama pada semua bagian bacaan sehingga selain waktu yang dibutuhkan lebih lama, juga kesulitan dalam mengidentifikasi gagasan utama.
Pembelajaran membaca yang terjadi dikelas biasanya dilakukan dengan prosedur sebagai berikut: (1) memberi sebuah teks berbahasa Indonesia yang diambil dari berbagai sumber, selain dari buku teks dengan alasan bacaannya kemungkinan sudah dibaca siswa, (2) meminta siswa membaca teks tersebut dalam waktu yang ditentukan guru, misalnya 15 menit, (3) meminta siswa mencari kata-kata yang dirasa sulit untuk dibahas bersama, (4) menugasi beberapa siswa untuk menyampaikan isi bacaan, (5) menugasi siswa mengerjakan soal (pilihan ganda atau isian singkat) yang telah disiapkan guru pada buku tugas dalam waktu yang telah ditentukan, (7) mengumpulkan buku tugas, (8) membahas jawaban soal-soal tersebut, serta (9) menilai hasil tes membaca. Dalam prosedur tersebut menunjukkan bahwa siswa tidak diberi kesempatan untuk melakukan aktivitas membaca melalui proses yang seharusnya, yaitu ada tahap prabaca lebih dahulu, kemudian tahap membaca, baru tahap pascabaca. Kegiatan membaca yang dilalui siswa selama ini adalah langsung pada tahap membaca dan diikuti tahap pascabaca.

Prabaca merupakan kegiatan yang dilakukan sebelum aktivitas membaca sesungguhnya (kegiatan inti membaca) dengan tujuan memperoleh gambaran awal guna membangun skematanya tentang isi bacaan. Menurut Porter (Frase, Patrick, \& Schumer, 2000:52), melalui prabaca, siswa dapat mengaktivasi prior knowledge atau pengetahuan awalnya dalam rangka merekonstruksi pemahaman baru (sejalan dengan prinsip-prinsip dalam pembelajaran konstruktivistis). Karena itu pelaksanaan prabaca penting dilatihkan kepada siswa sebelum mereka diberi tugas membaca agar kemampuannya dalam memahami suatu teks dapat meningkat.

Untuk mengaktivasi pengetahuan awal, ada beberapa strategi yang dapat diterapkan, yakni melalui pemberian gambaran awal, pembuatan peta pikiran, diskusi kelas, dramatisasi, serta pembuatan 
prequestion (Frase, Patrick, \& Schumer, 2000:53). Teknik pelaksanaan prabaca dengan pemberian gambaran awal dilakukan dengan guru memberi gambaran secara umum mengenai topik yang akan dibahas. Prabaca dengan pembuatan peta pikiran yakni guru menuliskan kata atau frase kunci yang terdapat dalam teks dan ditemukan dari kegiatan membaca sekilas, kemudian membuat hubungan-hubungan yang logis antara kata atau frase tersebut. Prabaca dengan diskusi kelas dilakukan dengan membicarakan berbagai hal mengenai topik utama dalam teks, baik secara klasikal maupun kelompok. Prabaca dengan dramatisasi berarti memeragakan apa yang ada dalam teks. Adapun prabaca dengan pembuatan prequestion dilakukan dengan membuat pertanyaan untuk dijawab melalui membaca teks secara intensif. Dari berbagai strategi tersebut, guru dan peneliti memilih pembuatan peta pikiran dengan alasan strategi tersebut dapat dilakukan siswa secara mandiri sehingga lebih memungkinkan untuk dlakukannya setiap kali melakukan aktivitas baca, sedangkan yang lainnya cenderung bergantung pada peran guru atau orang lain. Selain itu, strategi yang lain memerlukan waktu lebih lama dalam pelaksanaannya.

Kegiatan penelitian ini merupakan satu upaya mengefektifkan pembelajaran membaca intensif pada siswa agar prestasi yang dicapai dapat meningkat. Adapun secara rinci alasan pemilihan strategi tersebut dilakukan dengan pertimbangan sebagai berikut ini. Pertama, adanya peta pikiran (baik yang dibuat guru bersama siswa maupun siswa secara mandiri) dapat membantu siswa dalam mengatur fokus perhatiannya sehingga menghindarkannya dari pemberian fokus berlebihan pada bagian bacaan yang kurang penting, atau sebaliknya kurang memberikan perhatian pada bagian yang penting. Kedua, adanya pata semantik memungkinkan siswa dapat melakukan kegiatan membaca dengan tujuan yang jelas, yakni menemukan informasi untuk menemukan hubungan yang tepat antar kata-kata kunci yang telah diidentifikasi. Ketiga, dengan melatih siswa membuat peta pikiran berarti sekaligus telah melatihnya untuk berpikir kritis dan melakukan membaca dengan tujuan yang berbeda-beda. Keempat, dengan dilatihnya siswa melakukan prabaca sebelum kegiatan membaca dimulai, berarti pembelajaran tidak hanya difokuskan pada hasil, tapi juga pada proses panguasaan keterampilan membaca. Kelima, adanya hasil eksperimen Dole, Valencia, Greer, \& Waldrop (1991) dan Keally, Bakriwala, dan Sheridan (2003) bahwa peta pikiran lebih efektif daripada strategi lain pada kegiatan prabaca, yaitu pemberian gambaran awal, maupun pengadaan dramatisasi.

Yang menjadi masalah penelitian ini dapat dirumuskan sebagai berikut: (1) Bagaimanakah prosedur dan cara pembuatan peta pikiran untuk membantu siswa mengidentifikasi ide pokok dalam teks berita dari kegiatan prabaca? dan (2) Bagaimanakah prosedur dan cara memanfaatkan peta pikiran yang memuat ide pokok teks untuk membuat simpulan isi teks berita?

Berkenaan dengan proses pemahaman bacaan, Pearson dan Johnson (Nunan, 1992:66-67) menyatakan bahwa inti pemahaman berkaitan dengan satu prinsip yang sederhana, yaitu sebagai upaya membangun jembatan antara yang baru dengan yang sudah diketahui. Oleh karenanya, ada beberapa prinsip penting dalam aktivitas membaca pemahaman, yaitu: (1) Pemahaman merupakan proses aktif, bukan pasif. Adapun aktivitas itu tidak lain daripada menafsirkan apa yang dibaca sesuai dengan pengetahuan yang telah dimiliki mengenai topik yang dibacanya. Dengan demikian, pemahaman bukan sekedar masalah merekam secara harfiah tentang apa yang dibaca (mengingat), tetapi mengarah pada menganalisis, menyintesis, mengevaluasi, serta mengaplikasi; (2) Pemahaman memerlukan sejumlah besar pengambilan 
keputusan atau kesimpulan. Aktivitas ini sudah pasti memerlukan pemikiran yang kritis dan logis sehingga seringkali seorang pembaca kesulitan atau kebingungan tatkala harus membuat kesimpulan terhadap suatu bacaan yang sederhana sekalipun; dan (3) Pemahaman merupakan aktivitas dialog antara pembaca dan penulis. Oleh karenanya, pembaca yang baik tidak hanya menafsirkan apa yang ada dalam bacaan berdasarkan persepsinya sendiri, tetapi harus berupaya memaknainya seperti yang dimaksud penulisnya sehingga tidak terjadi misinterpretasi.

Mengingat prinsip-prinsip di atas, maka tidaklah mengherankan jika sebagian besar pembaca mengalami kesulitan untuk memahami suatu teks. Menurut hasil penelitian Byrnes (1998) dan Ferrari \& Palladino (2007) penyebab paling mendasar sehingga seseorang mengalami kesulitan dalam memahami isi bacaan adalah kebiasaan baca yang salah, yaitu meliputi: (1) terlalu banyak memperhatikan butir demi butir informasi, bagian demi bagian, kalimat demi kalimat, atau bahkan kata demi kata, (2) pandangan yang terlalu kuat terhadap suatu topik sehingga dalam menafsirkan isi wacana hanya berdasarkan satu sudut pandang saja, (3) kebiasaan menyuarakan setiap bacaan, padahal kerja otak dan pikiran jauh lebih cepat gerakan bibir, (4) kebiasaan membaca mundur, maksudnya mengulangulang kalimat yang sudah dibaca, dan (4) kebiasaan membaca terlalu cepat. Dari kelima kebiasaan buruk dalam membaca tersebut, penelitian Eskey (2002) menemukan bahwa kebiasaan membaca yang terlalu banyak memperhatikan butir demi butir informasi merupakan hal yang paling sering dilakukan pelajar.

Adanya kebiasaan memberikan perhatian pada butir demi butir informasi dalam teks mengindikasikan bahwa kegiatan membaca tersebut tidak diawali adanya tujuan yang jelas (Guzzeti, 1984:664). Padahal, penetapan tujuan menjadi pemandu utama untuk apa kita membaca dan itu harus dilakukan pembaca (siswa) sebelum melakukan aktivitas membaca yang sesungguhnya. Oleh Tompkins dan Hoskisson, penetapan tujuan dinyatakan sebagai bagian dari langkah awal dalam membaca dengan menerapkan pendekatan proses (1995:198). Proses yang dimaksud adalah proses membaca. Dengan menerapkan pendekatan itu, sebagaimana temuan Syamsi (2000), memungkinkan siswa berlatih membaca dengan melewati prosedur yang dapat membantunya memahami isi teks secara optimal. Adapun dari penelitian Palmer (1994) antara lain ditemukan bahwa siswa akan mendapatkan keuntungan jika proses membaca diperagakan di hadapan siswa, yaitu mendapat model membaca yang ideal.

Menurut Tompkins dan Hoskisson, dalam penerapannya, pendekatan proses dalam pembelajaran membaca mencakup tahap-tahap prabaca (persiapan untuk membaca), membaca, merespon, menggali teks, dan memperluas interpretasi (1995:32-56). Dengan demikian, proses membaca tidak dimulai dengan membuka buku dan langsung membaca, tetapi melalui persiapan. Adapun langkahlangkah dalam tahap prabaca adalah (1) memilih buku/bacaan, (2) menghubungkan buku/bacaan dengan pengalaman pribadi dan pengalaman membaca sebelumnya, (3) memprediksi isi buku/bacaan, dan (4) mengadakan tinjauan pendahuluan terhadap buku/bacaan. Pada tahap membaca, siswa membaca buku atau bacaan secara keseluruhan. Ada lima macam model membaca (Tomkins \& Hoskisson, 1995), yakni (1) membaca nyaring (reading aloud), (2) membaca bersama (shared reading), (3) membaca berpasangan (buddy reading), (4) membaca terbimbing (guided reading), dan (5) membaca bebas (independent reading). Pada tahap merespon, siswa memberi respon terhadap kegiatan membaca mereka dan terus berusaha memahami isi. Ada dua langkah yang dapat dilakukan siswa untuk tahap ini 
(Tomkins \& Hoskisson, 1995), yakni membaca dalam format membaca dan berpartisipasi dalam percakapan klasikal. Setelah memberi respon, para siswa melakukan tahap menggali teks yaitu kembali memperhatikan buku/bacaan untuk menggali isinya lebih dalam lagi dengan langkah-langkah: (1) membaca ulang buku/bacaan, (2) menguji keahlian khusus penulis (the author's craft), (3) mempelajari kosakata baru, dan (4) berpartisipasi dalam pengajaran singkat yang dilakukan guru. Adapun tahap terakhir, yaitu tahap memperluas interpretasi mencakup kegiatan-kegiatan: (1) memperluas interpretasi dan pemahaman, (2) merefleksikan pemahaman, dan (3) menilai pengalaman membaca (Tomkins \& Hoskisson, 1995). Ketiga kegiatan itu dapat dilakukan dengan melibatkan keterampilan berbahasa yang lain, seperti berbicara dan menulis, misalnya bermain peran/drama atau melakukan tugas/proyek.

Jika dilihat kembali tahap-tahap membaca seperti disarankan Tompkins dan Hoskisson di atas tampak bahwa terdapat begitu banyak kegiatan. Banyak pakar yang membuktikan bahwa prosedur proses membaca yang lebih sederhana ternyata lebih memungkinkan diterapkan oleh guru dalam pembelajaran juga lebih efektif meningkatkan kualitas proses pembelajaran. Seperti yang ditemukan Guzzeti, B.J. (1999: 667) bahwa pendekatan proses dengan tahap rereading (menggali teks kembali) menimbulkan kebosanan pada siswa sehingga mendorong guru tidak melatihkannya. Oleh karena itu, para pakar merekonstruksi formula yang disampaikan Tompkins dan Hoskisson dalam bentuk yang lebih sederhana.

Dari berbagai hasil penelitiannya, Horowitz merumuskan proses membaca meliputi tahap survey, question, read, recite, dan review (1996: 141). Ini berarti proses yang harus ditempuh adalah melakukan membaca sekilas dahulu, membuat membaca secara intensif, kemudian menyampaikan isi bacaan. Tahapan yang hampir sama dirumuskan oleh Francis P. Robinson (Ackersold \& Field, 1997: 23), yaitu survey, question, read, recite/recall, dan review atau diistilahkan dengan SQ3R. Beda antara keduanya adalah adanya tahap review, yaitu kegiatan mengulangi atau menelusuri kembali bagian-bagian tertentu dalam teks guna mendapatkan halhal penting yang seharusnya diingat. Jika diperhatikan, ketiga model pembagian tahap-tahap tersebut sama, yang pada intinya mencakup tahap prabaca, membaca, dan pascabaca. Pembagian tahap seperti ini pun dilakukan oleh Guzzeti, B. J. (1999) dan Urquhart \& Weir (1998).

Tahap prabaca merupakan kegiatan yang dilakukan sebelum kegiatan inti membaca untuk mengaktivasi pengetahuan awal maupun pengetahuan relevan yang sudah dimiliki siswa dalam rangka membangun pemahaman pembaca mengenai isi teks. Untuk itu, ada beberapa strategi yang dapat diterapkan, yakni melalui pemberian gambaran awal, pembuatan peta pikiran, diskusi kelas, dramatisasi, serta pembuatan prequestion (Frase, Patrick, \& Schumer, 2000:53). Teknik pelaksanaan prabaca dengan pemberian gambaran awal dilakukan dengan guru memberi gambaran secara umum mengenai topik yang akan dibahas. Prabaca dengan pembuatan peta pikiran yakni guru menuliskan kata atau frase kunci yang terdapat dalam teks dan ditemukan dari kegiatan membaca sekilas, kemudian membuat hubungan-hubungan yang logis antara kata atau frase tersebut. Prabaca dengan diskusi kelas dilakukan dengan membicarakan berbagai hal mengenai topik utama dalam teks, baik secara klasikal maupun kelompok. Prabaca dengan dramatisasi berarti memeragakan apa yang ada dalam teks. Adapun prabaca dengan pembuatan prequestion dilakukan dengan membuat pertanyaan untuk dijawab melalui membaca teks secara intensif. 
Tahap membaca, yaitu kegiatan membaca yang sesungguhnya atau kegiatan inti membaca yang dilakukan dengan kondisi diam atau silent way. Artinya, selama membaca yang bergerak adalah mata sehingga pembaca tidak boleh menyuarakan teks karena gerak mata lebih cepat daripada gerak bibir. Pada tahap ini beberapa strategi dan kegiatan dapat digunakan untuk meningkatkan pemahaman siswa. Strategi yang dimaksud meliputi strategi metakognitif, cloze procedure, dan pemanfaatan prequestion. Metakognitif berkaitan dengan pengetahuan seseorang untuk menggunakan intelektualnya dan usaha sadarnya dalam memonitor atau mengontrol penggunaan kemampuan intelektual tersebut. Cloze procedure merupakan cara meningkatkan pemahaman dengan menghilangkan sejumlah informasi dalam teks dan pembaca dituntut untuk mengisinya walau dalam hati untuk memperoleh pemahaman yang utuh tentang isi teks. Pemanfaatan prequestion dilakukan untuk memandu pembaca mengingat bagian-bagian penting dalam teks.

Tahap pascabaca, yaitu kegiatan yang dilakukan setelah membaca untuk membantu siswa dalam mengintegrasikan informasi baru ke dalam skemata yang sudah ada. Selain itu, kegiatan pascabaca dapat memperkuat dan mengembangkan hasil belajar yang diperoleh sebelumnya. Ada beberapa kegiatan dan strategi yang dapat dilakukan siswa setelah membaca, yaitu mengajukan pertanyaan, memperluas kesempatan belajar, menuturkan kembali isi bacaan, mengaplikasikan dalam praktik, dan mengadakan pementasan.

$$
\text { Sebagai }
$$

menumbuhkembangkan

upaya

keterampilan, pembelajaran membaca akan efektif apabila didukung oleh faktor-faktor baik yang berasal dari dalam diri siswa sendiri maupun dari luar siswa. Faktor dari dalam diri siswa yang dapat mendorong siswa aktif membaca adalah tumbuhnya motivasi. Ini dapat dibangkitkan dengan cara pemberian pembelajaran membaca yang menarik sehingga dapat menumbuhkan minat dan motivasi siswa. Mengenai hal ini, dari hasil penelitian Guthrie, Laurel, Stephen, \& Nicole (2007:307) diperoleh fakta bahwa melibatkan siswa dalam pemilihan cerita dan biografi tokoh yang diidolakan dapat meningkatkan motivasi siswa. Adapun temuan Guthrie, Laurel, Stephen \& Nicole (2007:310) yang lain menunjukkan bahwa pembelajaran membaca menjadi efektif apabila didukung oleh faktor eksternal yang berupa stimulan yang dapat memacu siswa untuk mendapatkan informasi dari bahan tekstual sehingga direkomendasikan agar kelas diisi kegiatan berbasis proyek atau pemecahan masalah. Fakta-fakta tersebut semakin menegaskan pentingnya penerapan tahap-tahap dalam pendekatan proses, terutama pangadaan prabaca.

Berdasarkan uraian di atas dapat disusun kerangka berpikir sebagai berikut ini. Para siswa kelas $8 \mathrm{D}$ mengalami kesulitan dalam memahami bacaan karena kurang mampu membedakan ide pokok dan ide pendukung. Oleh karenanya, semua bagian teks, kata demi kata, frase demi frase, dan kalimat demi kalimat dengan porsi perhatian yang sama.. Kondisi tersebut tidak terlepas dari strategi pembelajaran yang selama ini diterapkan, yaitu para siswa belum dilatih membaca melalui tahap prabaca terlebih dahulu. Padahal, tahap tersebut sangat penting karena melalui tahap itu siswa akan mendapatkan gambaran awal tentang apa yang akan dibacanya.

Salah satu teknik yang dinilai efektif dan efisien dalam tahap prabaca adalah pembuatan peta pikiran, yakni relasi antar kata kunci yang berkaitan dengan isi teks yang dirumuskan siswa bersama guru setelah membaca sekilas teks. Peta pikiran itu ditekankan pada bagian-bagian penting dalam teks. Melalui aktivitas tersebut, siswa akan dapat mengatur porsi perhatian pada bagian per bagian dalam teks yang dibacanya. Maksudnya siswa akan memberikan fokus perhatian yang lebih 
banyak pada bagian bacaan yang berkaitan dengan kata kunci dalam peta pikiran, sebaliknya lebih sedikit pada bagian lain yang kurang penting Dengan strategi tersebut, siswa lebih mudah dalam mengkonstruksi pikiran-pikiran pada tahap membaca sehingga kemampuan membacanya meningkat. Bila digambarkan dalam bagan, pemikiran tersebut dapat divisulaisasikan pada gambar 1 .

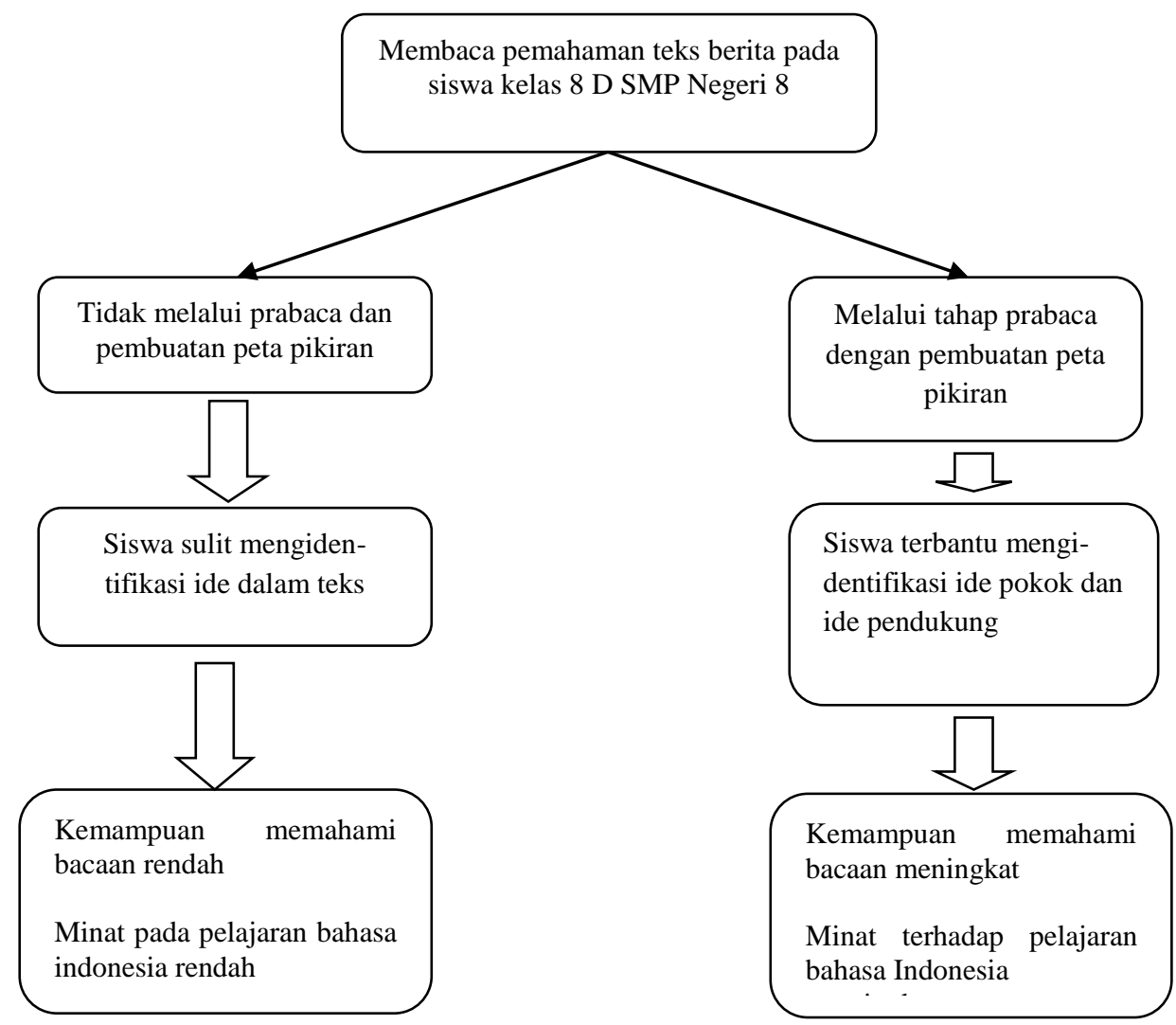

Gambar 1. Kerangka Berpikir

\section{METODE PENELITIAN}

Penelitian ini adalah penelitian tindakan kolaboratif, suatu metode untuk memberikan soluai terhadap masalah pembalajaran yang dilakukan melalui praktik, yang didasarkan pada teori dan kondisi lapangan di sekolah atau daerah tempat penelitian dilakukan (Oja \& Smulyan, 1989: 2-3). Penelitian dilakukan dalam tiga siklus, yang masing-masing melibatkan empat kegiatan: (1) perencanaan, (2) implementasi, (3) observasi dan interpretasi, dan (4) analisis dan refleksi untuk perencanaan lebih lanjut..

Yang menjadi partisipan ini adalah siswa kelas 8 D SMP Negeri 8 Surakarta pada tahun ajaran 2018/2019 karena memiliki kesulitan dalam membaca pemahaman. Mayoritas siswa berasal dari keluarga dengan golongan ekonomi menengah ke bawah yang dalam kehidupan sehari-harinya menggunakan bahasa Jawa, baik di rumah maupun di luar rumah, bahkan di sekolah. Hal tersebut sangat berpengaruh terhadap penguasaannya pada kosa kata dan srtuktur kalimat bahasa Indonesia sehingga berdampak pula terhadap kemampuan siswa dalam menangkap makna suatu teks berbahasa Indonesia. Adapun yang menjadi objek penelitian adalah pembelajaran membaca intensif atau pemahaman pada mata pelajaran Bahasa Indonesia. Ini perlu peneliti sampaikan karena pelajaran membaca di kelas 8 SMP meliputi membaca pemahaman (intensif), membaca cepat, membaca memindai, dan 
membaca ekstensif. Akan tetapi, di antara berbagai kegiatan membaca tersebut, yang dirasa paling sulit oleh siswa adalah membaca intensif.

Yang menjadi sumber data dalam penelitian tindakan kelas ini adalah peristiwa pembelajaran membaca intensif, informan (siswa dan guru), serta dokumen (hasil tes membaca dan catatan penunjang). Karena itu, pengumpulan datanya dilakukan melalui teknik observasi, wawancara, dan analisis dokumen. Untuk menganalisis data yang diperoleh dari hasil pengamatan dan wawancara (berupa data kualitatif) serta data dari hasil tes membaca (data kuantitatif) dilakukan dengan análisis kritis, yakni membandingkan data dari siklus satu ke siklus berikutnya. Hal itu untuk mengidentifikasi kelemahan dan kekuatan tindakan yang telah dilakukan sehingga dapat ditetapkan langkah perbaikan pada pelaksanaan tindakan berikutnya.

Untuk mengukur ketercapaian tujuan penelitian dirumuskan indikatorindikator yang dirumuskan pada tabel 1 .

Tabel 1: Indikator Ketercapaian Tujuan Penelitian

\begin{tabular}{|c|c|c|}
\hline Aspek & $\begin{array}{c}\text { Pencapaian } \\
\text { minimal }\end{array}$ & Cara mengukur \\
\hline $\begin{array}{l}\text { Keaktifan dan keantusiasan } \\
\text { siswa dalam pembelajaran } \\
\text { membaca, dari apersepsi }\end{array}$ & $75 \%$ & $\begin{array}{l}\text { Diamati saat pembelajaran dan } \\
\text { dihitung dari jumlah siswa yang } \\
\text { menampakan keaktifan dan }\end{array}$ \\
\hline hingga evaluasi & & keantusiasan selama pembelajaran \\
\hline $\begin{array}{l}\text { Kemampuan siswa dalam } \\
\text { merumuskan peta pikiran } \\
\text { secara tertulis dari hasil } \\
\text { membaca judul maupun isi } \\
\text { teks secara sekilas }\end{array}$ & $75 \%$ & $\begin{array}{l}\text { Diukur pada saat pembelajaran dan } \\
\text { dihitung dari jumlah siswa yang dapat } \\
\text { merumuskan peta pikiran yang benar- } \\
\text { benar berkaitan dengan topik bacaan }\end{array}$ \\
\hline $\begin{array}{l}\text { Kemampuan siswa dalam } \\
\text { memahami isi bacaan }\end{array}$ & $70 \%$ & $\begin{array}{l}\text { Diukur dari hasil tes membaca dan } \\
\text { dihitung dari jumlah siswa yang dapat } \\
\text { mencapai batas KKM pada tes } \\
\text { membaca }\end{array}$ \\
\hline
\end{tabular}

\section{HASIL DAN PEMBAHASAN}

\section{Hasil Penelitian}

Penelitian

tindakan

tentang

pembelajaran membaca pemahaman teks berita dilakukan dalam 3 siklus yang setiap siklus menggunakan waktu satu atau dua kali pertemuan. Setiap pertemuan menggunakan waktu $2 \times 40$ menit. Yang menjadi buku sumber adalah buku teks "Pelajaran Bahasa Indonesia Kelas 8 untuk SMP dan MTs" yang diterbitkan oleh Pusat perbukuan Departemen Pendidikan Nasional, tahun 2017. Semua siswa kelas 8 mendapat pinjaman buku teks tersebut dari sekolah sehingga membantu kelancaran pembelajaran menulis. Hasil pelaksanaan setiap siklus penelitian dideskripsikan sebagai berikut ini.

\section{Deskripsi Siklus I}

Tahap perencanaan pada siklus pertama diawali dengan penyusunan rencana pelaksanaan pembelajaran RPP oleh guru Bahasa Indonesia. Standar kompetensi yang digunakan adalah siswa mampu memahami ragam teks/bacaan dengan berbagai cara membaca. Adapun kompetensi dasarnya adalah membaca intensif untuk mengemukakan menemukan ide pokok dan membuat simpulan isi berita. Berdasarkan kompetensi dasar tersebut, guru merumuskan indikator sebagai berikut: (1) siswa mampu mengidentitifaksi ide pokok teks berita; (2) siswa mampu membuat peta pikiran berdasarkan ide pokok yang ditemukan; dan (3) siswa mampu menyatakan 
simpulan teks berita berdasarkan peta pikiran yang dibuatnya. Berdasarkan indikator di atas, guru dibantu peneliti memilih materi bacaan yang sesuai, yaitu teks berita dari beberapa sumber. Naskah berita untuk latihan diambil dari surat kabar. Pembelajaran dilakukan dalam dua kali tatap muka dengan waktu 2 x 2 x 40 menit.

Pada tahap pelaksanaan, yang menjadi pengajar adalah dosen Bahasa Indonesia. sedangkan yang menjadi pengamat adalah guru Bahasa Indonesia sebagai kolaborator. Proses pembelajarannya sebagai berikut: (1) melalui penyebutan nama-nama pulau Indonesia Timur, kelas dibagi menjadi 6 kelompok (6-7 siswa setiap kelompok, (2) sambil bertepuk tangan menyanyikan lagi "Dari Sabang sampai Merauke" siswa bergabung bersama kelompok masingmasing kemudian duduk (diusahakan posisi berhadapan), (3) Masing-masing siswa mendapat satu naskah berita berjudul, (4) Siswa memperhatilan informasi tata cara menemukan gagasan pokok dalam berita yang dibaca dengan mudah, yaitu memfokuskan perhatian pada bagian berita yang penting-penting saja, (3) Siswa ditugasi membaca naskah selama 5 menit untuk menemukan gagasan pokok, (4) Siswa memperhatikan dosen yang menulis satu kata kunci di tengah papan tulis, yaitu GEMPA kemudian diberi lingkaran, (5) Siswa memperhatilkan aturan main dalam merespon pertanyaan dosen, yaitu kelompok mana yang tunjuk jari paling dahulu, itulah yang berkempatan menulis jawaban di papan tulis. Kalau jawaban benar, skornya 1 . Kelompok pemenang adalah yang skornya paling banyak. (Dosen menulis nama kelompok di kanan atas papapn tulis untuk memberi skor)

Kegiatan selanjutnya adalah (6) Siswa merespon pertanyaan dosen, "Apa yang dibahas dalam berita tadi berkaitan dengan adanya gempa?" (Tsunami), (7) Salah satu siswa menuliskan kata TSUNAMI di sebelah kata GEMPA, kemudian memberi lingkaran, (8) Siswa merespon pertanyaan dosen, "Di mana kejadian peristiwa yang ada dalam berita tadi?" (Lombok Utara), (9) Salah satu siswa menuliskan kata LOMBOK UTARA di sebelah kata TSUNAMI, kemudian memberi lingkaran, (10) Siswa merespon pertanyaan dosen, "Kapan kejadian peristiwa yang ada dalam berita tadi?" (........), (11) Salah satu siswa menuliskan kata .... di sebelah kata LOMBOK UTARA, kemudian memberi lingkaran. Kemudian berturut-turut menuliskan kata kunci lain yang menjadi gagasan pokok berita, (12) Siswa memperhatikan contoh dosen dalam memberi garis penghubung antara kata GEMPA dan kata TSUNAMI, (13) Siswa memperhatikan tawaran dosen "Siapa yang bisa memberi garus penghubung kedua?", (14) Salah satu siswa yang mewakili kelompok yang tunjuk jari paling awal memberikan garis antar gagas pokok. Demikian berturut-turut sampai semua ide pokok memiliki garis penghubung, (15) Siswa memperhatikan dosen yang memberi contoh cara menyatakan kembali isi berita

Pada kegiatan lanjutannya sebagai berikut (16) Salah satu siswa mewakili kelompoknya untuk menyatakan ringkasan berita. Demikian berturut-turut sampai semua kelompok selesai tampil, (17) Sisw bersama dosen menyimpulkan nama tennik yang telah dilakukan, yaitu PETA PIKIRAN, (18) Siswa bersama dosen menentukan kelompok dengan penampilan terunggul dan bertepuk tangan bersama, (19) Setiap siswa mendapat teks berita kedua dan selembar kertan manila dan sebuah spidol, (20) Bersama kelompoknya, siswa memperhatikan tugas membaca dan membuat peta semantik pada kertas manila dalam waktu 10 menit, serta menuliskan judul berita di atas peta semantik.

Kegiatan pembelajharan inti selanjutnya adalah (21) Siswa bersama kelompoknya membaca secara cepat isi berita, kemudian membuat peta semantik, (22) Siswa mengevaluasi peta semantik 
bersama kelompoknya, (23) Kelompok yang sudah selesai mengevaluasi segera mengacungkan tangan untuk dicatat di papan tulis, (24) Setiap kelompok diwakili 3 orang untuk presentasi (2 orang memegang kertas manila, satu orang presentasi), sementara dosen menulis skor setiap kelompok di papan tulis, dan (25) Siswa bersama dosen menetapkan perolehan skor dan menentukan urutan kualitas kerja kelompok.

Hasil observasi terhadap proses maupun hasil pembelajaran pada siklus 1 jika dikaitkan dengan indikator ketercapaian tujuan penelitian adalah sebagai berikut ini. Pertama, $50 \%$ siswa (20 orang) menunjukkan sikap pasif dan kurang antusias dalam mengikuti pembelajaran membaca. Ada yang tidak memperhatikan teks bacaan yang diterimanya, tidak mau menuliskan katakata kunci ketika ditunjuk guru, beberapa kali minta izin ke belakang, tidak mau melakukan aktivitas membaca intensif, dan ada juga yang tidak mengumpulkan pekerjaannya yang berisi hasil identifikasi kata-kata kunci berdasarkan hasil membaca sekilas dan membaca secara intensif. Kedua, $50 \%$ siswa (13 orang) belum mampu mengidentifikasi kata-kata kunci yang relevan dengan isi berita dan belum bisa membuat peta pikiran dengan benar. Ketiga, $60 \%$ siswa (24 orang) siswa belum mampu memahami isi bacaan karena nilai yang diperoleh kurang dari 70 .

Hasil refleksi adalah sebagai berikut ini. Pertama, banyaknya siswa yang masih bersikap pasif dan kurang termotivasi dalam pembelajaran membaca intensif disebabkan materi bacaan yang kurang diminati siswa, penyampaian materi, termasuk pemberian contoh pembuatan peta pikiran dilakukan terlalu cepat, dan tidak semua siswa mendapat bimbingan membaca. Selain itu, keterbatasan waktu membuat pengajar tidak bisa melakukan pembimbingan pada semua siswa sehingga para siswa merasa kurang diperhatikan. Untuk mengatasi masalah itu, penelti dan guru akan memperbaikinya pada siklus kedua dengan memilih topik berita yang diperkirakan disukai siswa. Selain itu, aktivitas membuat peta pikiran membaca akan dilakukan secara berkelompok sehingga memungkinkan guru member bimbingan pada semua siswa. Kedua, masih banyaknya siswa yang belum mampu mengidentifikasi kata kunci yang relevan dengan ide pokok dalam berita menunjukkan bahwa mereka belum memiliki informasi yang cukup tentang peristiwa yang dibicarakan dalam teks bacaan. Karena itu, para siswa harus menggunakan bantuan kata tanya apa, siapa, di mana, dan kapan yang mengarah pada pertanyaan ingatan dan merumuskan pertanyaan yang langsung mengarah pada hal-hal umum tentang ide pokok tersebut. Oleh karena itu, pada siklus berikutnya identifikasi dilakukan setelah siswa membaca sekilas isi berita secara keseluruhan. Ketiga, masih banyaknya siswa yang belum mencapai ketuntasan belajar menunjukkan adanya kesulitan memahami bacaan yang diberikan. Dari keterangan siswa, hal tersebut berkaitan dengan waktu yang diberikan untuk melakukan aktivitas baca terlalu pendek.

\section{Deskripsi Siklus II}

Tahap perencanaan pada siklus pertama diawali dengan penyusunan rencana pelaksanaan pembelajaran RPP oleh guru Bahasa Indonesia. Standar kompetensi yang digunakan adalah siswa mampu memahami ragam teks/bacaan dengan berbagai cara membaca. Adapun kompetensi dasarnya adalah membaca intensif untuk mengidentifikasi makna gagasan utama, pendukung serta informasi faktual dalam teks berita. Berdasarkan kompetensi dasar tersebut, guru merumuskan indikator sebagai berikut: (1) siswa mampu mampu membedakan gagasan utama dan gagasan pendukung dalam bacaan, (2) siswa mampu menentukan informasi-informasi pokok dalam berita, dan (3) siswa mampu mengungkapkan hal-hal pokok pada berita dalam bahasa sendiri. Berdasarkan 
indikator di atas, dipilih beberapa materi bacaan yang sesuai, yaitu teks berita dengan tema pelestarian pertunjukan seni tradisional. Sesuai dengan rekomendasi yang ditetapkan pada siklus I, pemilihan materi melibatkan siswa sehingga relevan dengan minat mereka. Karena itu, guru menyiapkan empat berita dan pada beberapa kesempatan meminta siswa untuk memilih dua di antaranya. Adapun waktu yang digunakan dalam pembelajaran adalah dua kali tatap muka ( $2 \times 2 \times 40$ menit).

Pada tahap pelaksanaan, yang menjadi pengajar adalah guru Bahasa Indonesia, sedangkan yang menjadi pengamat adalah dosen bersama guru Bahasa Indonesia kelas VIII. Proses pembelajaran adalah sebagai berikut: (1) Guru membagi kelas menjadi 6 kelompok sehingga setiap kelompok beranggotakan 4 atau 5 orang dengan cara secara berurutan siswa menyebutkan kedelapan seni tradisional yang telah disebutkan guru, yaitu wayang orang, wayang kulit, kethoprak, jathilan, tayuban, ludruk, thok prol, dan reog. Selanjutnya kelompok yang terbentuk dinamai sesuai dengan seni tradisional yang disebutkan; (2) Guru membagikan berita berjudul "Wayang Gong, Seni Tradisi yang Nyaris Punah" sejumlah 3 teks untuk setiap kelompok; (3) Siswa bersama kelompoknya diminta mencermati judul dan membaca sekilas isi teks dalam waktu 5 menit; (4) Guru memberi sebuah contoh kata kunci yang relevan dengan judul dan isi teks bacaan, dan menuliskannya di papan tulis yaitu wayang gong ; (5) Siswa diminta merumuskan kata kunci lain yang relevan dengan judul dan hasil membaca isi teks secara sekilas dengan menggunakan kata tanya $5 \mathrm{~W}+1 \mathrm{H}$ bersama kelompoknya di bawah bimbingan guru. Kata-kata kunci tersebut dituliskan pada kertas folio yang kemudian dibuat peta pikirannya; (6) Salah satu siswa dari setiap kelompok menyampaikan secara tertulis (di papan tulis) peta pikiran yang telah dirumuskan; (7) Siswa bersama guru memantapkan peta pikiran yang relevan dengan teks; (8) Siswa diminta mengingat-ingat peta pikiran yang telah dirumuskan sehingga ketika melakukan aktivitas membaca tidak perlu melihat catatan; (9) Siswa diminta membaca dengan tidak bersuara dalam rangka menguji kebenaran peta pikiran bersama kelompoknya dalam waktu 10 menit untuk menemukan jawaban atas kalimat-kalimat tanya yang ada pada bagian awal bacaan.; (10) Guru secara lisan bertanya kepada para siswa mengenai kebenaran kata-kata kunci dan hubungan makna antar kata kunci pada peta pikiran; (11) Siswa bersama guru membahas pengembangan peta pikiran dan menambahkan kata-kata kunci yang belum tertulis serta membuat hubungan makna pada peta pikiran; (12) Siswa membaca dengan tanpa bersuara bacaan tersebut dengan tujuan menemukan jawaban terhadap peta pikiran yang dibuat selama 10 menit; (14) Guru memberi soal uraian kepada semua kelompok untuk mengukur pemahaman siswa terhadap isi bacaan; dan (13) Guru bersama siswa membahas peta pikiran sekaligus melakukan koreksi dan menuliskan jumlah jawaban yang betul pada pekerjaannya, kemudian mengumpulkannya kepada guru.

Hasil observasi terhadap proses maupun hasil pembelajaran pada siklus II bila dikaitkan dengan indikator ketercapaian tujuan penelitian adalah sebagai berikut ini. Pertama, $25 \%$ siswa (6 orang) menunjukkan sikap pasif dan kurang antusias dalam mengikuti pembelajaran membaca. Hal tersebut diindikasikan dari adanya siswa yang tidak ikut membaca sekilas teman sekelompoknya, tidak turut membuat pertanyaan, dan tampak tidak serius dalam melakukan aktivitas membaca. Kedua, 30 $\%$ siswa ( 7 orang) belum mampu membuat peta pikiran dari hasil membaca sekilas teks dengan tepat. Ini dapat diidentifikasi dari pertanyaan yang dirumuskan kelompoknya secara tertulis sebelum membuat peta pikiran. Para siswa masih lebih banyak menanyakan 
informasi yang bersifat ingatan atau faktual dengan hanya menggunakan kata tanya siapa, apa, kapan, dan di mana, tidak merumuskan pertanyaan yang bersifat pemahaman. Ketiga, 40\% siswa (10 orang) siswa belum mampu memahami seluruh isi bacaan karena nilai kelompok yang diperoleh kurang dari 70.

Refleksi yang dilakukan mencakup kegiatan mengidentifikasi penyebab berlum tercapainya indikator peneltian dan menetapkan langkah untuk mengatasinya, sedangkan hasilnya adalah sebagai berikut ini. Pertama, masih ada siswa yang bersikap pasif dan kurang termotivasi dalam melakukan tugas kelompok disebabkan teman kelompoknya yang terlalu mendominasi aktivitas kelompok. Selain itu, kemampuan membaca siswa tersebut juga kurang memadai sehingga merasa tertinggal oleh temannya. Untuk itu, penelti dan guru akan memperbaikinya pada siklus ketiga dengan menetapkan anggota kelompok yang setara kemampuan membacanya sehingga tidak ada salah satu yang mendominasi kinerja kelompok. Selain itu, akan melakukan pemantauan secara intensif proses kerjasama dalam kelompok. Kedua, ada siswa yang belum mampu membuat peta pikiran dengan menggunakan kata tanya $5 \mathrm{~W}+1 \mathrm{H}$ yang mengarah pada pertanyaan pemahaman menunjukkan bahwa mereka belum memiliki informasi yang cukup tentang isi teks. Karena itu, para siswa hanya menggunakan kata tanya apa, siapa, di mana, dan kapan yang mengarah pada pertanyaan ingatan dan merumuskan pertanyaan yang mengarah pada hal-hal yang berkaitan dengan judul teks tersebut. Dari hasil wawancara dengan siswa dan diskusi dengan guru diidentifikasi faktor penyebabnya, yaitu karena siswa tidak memahami maksud membaca sekilas sehingga menggantinya dengan melakukan membaca intensif. Mengingat waktu yang diberikan hanya 5 menit, kegiatan membacanya belum selesai. Karena itulah, pembuatan peta pikiran dilakukan hanya berdasarkan dari membaca judul teks.
Untuk mengatasi hal ini, pada siklus berikutnya guru akan memberi penjelasan tentang membaca sekilas dan perbedaannya dengan membaca intensif. Ketiga, masih banyaknya siswa yang belum mencapai ketuntasan belajar menunjukkan adanya kesulitan memahami bacaan yang diberikan. Dari keterangan siswa, hal tersebut berkaitan dengan materi bacaan yang diberikan untuk melakukan aktivitas baca, yakni banyak singkatan kata dan kata-kata baru. Untuk mengatasi masalah tersebut peneliti menetapkan untuk membahas singkatan dan atau kata teknis terlebih dahulu bila ada dalam teks sebelum membaca sekilas.

\section{Deskripsi Siklus III}

Tahap perencanaan pada siklus ketiga, dilakukan dengan menyusun RPP perbaikan meskipun standar kompetensi yang digunakan sama dengan siklus sebelumnya, yaitu siswa mampu memahami ragam teks/bacaan sastra dengan berbagai cara membaca. Kompetensi dasarnya adalah membaca intensif berita dan menuliskannya kembali dalam beberapa kalimat. Berdasarkan kompetensi dasar tersebut, guru merumuskan indikator sebagai berikut: (1) siswa mampu menemukan unsur-unsur instrinsik dalam berita, yaitu tema, penokohan, setting, dan amanat serta (2)siswa mampu menuliskan kembali beberapa kalimat berdasarkan isi berita yang dibaca. Sebagai sumber pembelajaran, dipilih materi bacaan berita yang sesuai dengan tema, yaitu tentang pendidikan. Kedua berita tersebut akan digunakan dalam pembelajaran yang berlangsung dua kali tatap muka dalam waktu 2 x 40 menit.

Pada tahap pelaksanaan, proses pembelajarannya adalah sebagai berikut: (1) Guru menyampaikan bagian-bagian yang menarik dari berita; (2) Siswa bersama guru mengidentifikasi tokoh dan perilaku yang patut ditiru, (3) Guru mengelompokkan siswa yang setiap kelompok terdiri atas 2 orang siswa dengan 
dasar kemampuan membaca yang setara (sebagai tindak lanjut dari hasil refleksi siklus kedua) sehingga ada 13 kelompok; (4) Setiap kelompok diminta membaca berita dalam buku teks berjudul "Piano Hati Reza" kemudian diminta mengidentifikasi kata-kata yang sulit dipahami. Siswa menemukan ada tiga kata yang perlu dianggap asing, yaitu tuts, aransemen, dan non sense; (5) Guru bersama siswa mendiskusikan makna katakata yang dirasa sulit tersebut, misalnya non sense artinya tidak mungkin terjadi dan membuat kalimat lain dengan menggunakan kata tersebut; (6) Guru memberi penjelasan tentang perbedaan kegiatan membaca sekilas yang diterangkan guru dalam bahasa siswa, yaitu sama dengan membaca grambyangan atau membaca dengan cepat; (7) Siswa bersama teman satu kelompoknya membaca sekilas berita atau membaca secara cepat dan waktunya ditetapkan oleh guru, yaitu selama 5 menit; (8) Siswa merumuskan hal-hal yang ingin diketahuinya tersebut dalam kalimatkalimat tanya yang menggunakan kata tanya $5 \mathrm{~W}+1 \mathrm{H}$ di bawah bimbingan guru untuk mempermudah siswa menemukan kata-kata kunci; (9) Siswa diminta membuat hubungan makna antarkata kunci dan membuat pemetaan makna; (11) Beberapa kelompok diminta menyampaikan sebagian peta pikirannya untuk ditulis pada papan tulis; (12) Guru bersama siswa membahas peta pikiran yang telah dibuat dan menetapkan peta pikiran yang tepat; (13) Siswa diminta mengingat-ingat peta pikiran; (14) Siswa membaca berita secara intensif dengan waktu yang telah ditetapkan dan berupaya melengkapi peta pikiran yang telah dibuat berdasarkan hasil membaca sekilas; (15) Siswa menuliskan isi berita yang telah dibaca dalam beberapa kalimat; dan (16) Siswa dan guru melakukan koreksi terhadap pekerjaan masing-masing kelompok

Hasil observasi terhadap proses maupun hasil pembelajaran pada siklus III jika dikaitkan dengan indikator ketercapaian tujuan penelitian adalah sebagai berikut: (1) $15 \%$ siswa (4 orang) menunjukkan sikap pasif dan kurang antusias dalam mengikuti pembelajaran membaca, (2) $15 \%$ siswa (4 orang) belum mampu membuat peta pikiran dari hasil membaca sekilas teks sebagaimana yang dipersyaratkan guru, yang mengarah pada pertanyaan ingatan dan pemahaman $\mathrm{s}$ dengan tepat. Ini dapat diidentifikasi dari pertanyaan yang dirumuskannya secara tertulis. Para siswa tersebut hanya menanyakan informasi yang bersifat ingatan atau faktual, dan (3) $25 \%$ siswa (6 orang) siswa belum mampu memahami isi bacaan karena nilai yang diperoleh kurang dari 70.

Hasil refleksi adalah sebagai berikut ini.Pertama, siswa yang masih bersikap pasif dan kurang termotivasi dalam pembelajaran membaca intensif diidentifikasi hanya terjadi pada yang kemampuan membacanya rendah. Kedua, masih adanya siswa yang belum mampu membuat peta pikiran dengan menggunakan bantuan kata tanya $5 \mathrm{~W}+1$ $\mathrm{H}$ (yaitu apa, siapa, di mana, kapan, mengapa, dan bagaimana) yang mengarah pada pertanyaan pemahaman menunjukkan bahwa mereka belum memiliki informasi yang cukup dari hasil membaca sekilas tentang informasi pokok dalam teks. Karena itu, para siswa hanya menggunakan kata tanya apa, siapa, di mana, dan kapan yang mengarah pada pertanyaan ingatan dan merumuskan pertanyaan yang langsung mengarah pada hal-hal yang sesuai dengan judul teks.. Berdasarkan hasil wawancara dengan siswa dan diskusi antara peneliti dengan guru dapat diidentifikasi faktor penyebabnya, yaitu karena siswa belum mampu melakukan membaca sekilas secara memadai. Oleh karena itu, guru perlu memberi latihan membaca sekilas secara intensif terhadap para siswa tersebut, terutama pada saat diadakannya pembelajaran membaca cepat. Ketiga, masih adanya siswa yang belum mencapai ketuntasan belajar menunjukkan 
adanya kesulitan memahami bacaan yang diberikan. Dari keterangan guru, hal tersebut lebih berkaitan dengan indikator nomor dua di atas, yaitu siswa masih membaca dengan bersuara karena kemampuan membacanya rendah.

\section{Deskripsi Antarsiklus}

Berdasarkan deskripsi hasil tindakan setiap siklus dapat dibuat rekapitulasi perkembangan kualitas proses dan hasil pembelajaran antarsiklusnya seperti pada tabel 3.

Tabel 3: Rekapitulasi Ketercapaian Indikator Penelitian Tiga Siklus

\begin{tabular}{l} 
Indikator \\
No \\
\hline 1 Keaktifan dan keantusiasan siswa dalam pembe \\
2 Kemampuan siswa dalam membuat peta pikira \\
membaca teks berita \\
Siswa yang mampu memahami isi bacaan (men \\
benar 70\% soal bacaan) \\
Berdasarkan data pada tabel 3 dapat \\
dinyatakan bahwa rata-rata terjadi \\
peningkatan persentase ketercapaian \\
ketiga indikator sebanyak 35\% pada \\
penerapan tindakan dalam penelitian ini \\
(dari siklus I hingga siklus III). \\
Peningkatan tertinggi adalah pada \\
indikator kedua pada siklus pertama dan \\
kedua, yaitu bertambahnya jumlah siswa \\
yang mampu membuat peta pikiran dari \\
hasil membaca judul maupun isi teks \\
secara sekilas dan yang mampu memahami \\
isi bacaan, yakni $30 \%$. Tampak bahwa \\
pada siklus I yang bisa membuat peta \\
pikiran hanya 40\% siswa (11 orang), \\
namun pada siklus II sudah mencapai $70 \%$ \\
(20 orang). Selain itu, pada siklus I yang \\
mampu mencapai nilai tes membaca \\
minimal 70 hanya 40\% (11 orang), pada \\
siklus III menjadi 75\% (21 orang). Jika \\
dibandingkan dengan indicator \\
ketercapaian tujuan, hasil tindakan pada \\
siklus III ini dapat dinyatakan sudah \\
mencapai target, bahkan melampauinya. \\
Karena itu, penelitian tidak dilanjutkan \\
lagi. Akan tetapi, guru menyatakan akan \\
melaksanakan hasil refleksi siklus III.
\end{tabular}

\section{Pembahasan}

\section{Pembuatan Peta Pikiran Dilakukan Setelah Membaca Sekilas Isi Teks}

Dari hasil pelaksanaan tindakan siklus I diketahui bahwa sebagain besar siswa hanya menentukan ide pokok yang bersifat ingatan dari membaca judul teks.
Persentase ketercapaian

\begin{tabular}{ccc}
\hline Siklus I & Siklus II & Siklus III \\
\hline $50 \%$ & $75 \%$ & $85 \%$ \\
$40 \%$ & $70 \%$ & $85 \%$ \\
$40 \%$ & $60 \%$ & $75 \%$ \\
\hline
\end{tabular}

Tentu saja hal tersebut tidak sesuai dengan tujuan penelitian tindakan ini, yakni mengarah pada pemahaman bacaan sehingga peta pikiran yang dirumuskan mestinya pada tingkatan pemahaman. Ini sejalan dengan pendapat Thalheimer (2003:5) bahwa pemakaian pertanyaan prabaca akan lebih bermanfaat jika mencakup pertanyaan level lebih tinggi, yaitu dari tipe pemahaman dan aplikasi, dan pertanyaan yang penting secara struktural. Dinyatakannya siswa akan memperoleh keuntungan yang besar dari pertanyaan semacam itu. Adapun pembagian tipe-tipe pertanyan tersebut mengacu pada Bloom yang membedakannya sebagai berikut: (1) tipe pengetahuan, (2) pemahaman, (3) aplikasi, (4) analisis, (5) sintesis, dan (6) evaluasi (Bloom, et al.,1984). Oleh karenanya, pada penelitian ini siswa didorong untuk membuat prequestion pada tingkat pemahaman.

Strategi yang ditempuh untuk menagkomodasi agar peta pikiran buatan siswa mengarah pada tingkat pemahaman dilakukan dengan cara meminta siswa tidak hanya membaca judul tetapi, membaca sekilas isi tesk terlebih dahulu. hasilnya sebagian besar siswa dapat membuat peta pikiran tingkat pemahaman. Itu menunjukkan dengan membaca sekilas, siswa memiliki informasi yang memadai untukmembuat peta pikiran tingkat pemahaman. 
Optimalisasi Pembuatan Peta Pikiran Tingkat Pemahaman melalui Bimbingan Guru dan Kerja Kelompok

Peta pikiran pada prabaca yang disusun siswa secara mandiri umumnya lebih mengarah pada tipe ingatan atau pada fakta-fakta yang akan sangat mudah untuk dijawab (Dole, Valencia, Greer, \& Waldrop, 1991). Hal tersebut juga terjadi pada penelitian ini. Misalnya pada siklus I, ketika siswa membuat peta pikiran secara mandiri, hasilnya sebagian besar kata kunci dan peta pikiran yang dibuat mengarah pada tingkat ingatan, yakni menanyakan hal yang umum mengenai tokoh yang dibicarakan dalam teks. Akan tetapi, setelah siswa menyusunnya dengan bimbingan guru dan bersama temannya (siklus II dan III), terjadi peningkatan kualitas peta pikiran yang disusun siswa, yakni sudah banyak yang bertipe pemahaman.

Fenomena tersebut selaras dengan tenuan Readence, Moore, \& Rickelman (2000: 67) bahwa untuk mencegah hal itu, memberikan solusi, yakni guru harus memberikan bimbingan dengan cara meminta siswa membuat pertanyaan berdasarkan judul teks yang menggunakan kata tanya why dan how. Misalnya dari judul bacaan "Politik Uang pada Pileg", dapat dibuat pertanyaan: Bagaimana hal itu dilakukan? Mengapa caleg melakukan hal itu? Bagaimana dampak terhadap kinerjanya kalau caleg tersebut terpilih?

Selain dengan bimbingan guru, pembuatan peta pikirann yang bersama teman juga terbukti lebih baik daripada dibuat secara mandiri. Sebagaimana yang dilakukan pada siklus II dan III, siswa membaca sekilas dan membuat prequestion dalam kelompok kecil, yaitu terdiri atas 2 orang, sebagai upaya menumbuhkembangkan suatu keterampilan, pembelajaran membaca akan efektif apabila didukung oleh faktor-faktor baik, yang berasal dari dalam diri sendiri maupun dari luar siswa. Faktor dari dalam diri siswa yang dapat mendorong siswa aktif membaca adalah tumbuhnya motivasi. Ini dapat dibangkitkan dengan cara pemberian pembelajaran membaca yang menarik sehingga dapat menumbuhkan minat dan motivasi siswa. Mengenai hal ini, dari hasil penelitian Guthrie, Laurel, Stephen, \& Nicole (2007) diperoleh fakta bahwa mengondisikan siswa untuk berbagi bacaan sekaligus memberi komentar terhadap bacaan tersebut dengan temannya dapat meningkatkan motivasi dalam pembelajaran membaca.

\section{Pembuatan Peta Pikiran Meningkatan Pemahaman terhadap Isi Teks}

Dengan memperhatikan data pada tabel 3 dapat disimpulkan bahwa seiring dengan meningkatnya persentase siswa yang mampu membuat peta pikiran menunjukkan adanya peningkatan persentase siswa yang mampu memahami bacaan, yakni yang memperoleh nilai tes minimal 70. Ini berarti ada korelasi antara keberhasilan dalam membuat prequestion dengan pemahaman terhadap isi bacaan. Hal ini relevan dengan hasil penelitian Dole, Valencia, Greer, \& Waldrop (1991) yang melakukan pengujian terhadap efek bacaan yang pada bagian awalnya diberi peta pikiran dengan yang tidak diberi terhadap tingkat pemahaman siswa dan ditemukan para siswa yang diberi bacaan denganpeta pikiran lebih tinggi tingkat pemahamannya. Selain itu, juga dengan kajian Hartley \& Davies (2006) dan Levin \& Pressley (1981) terhadap dua kelompok siswa yang diberi teks dengan tingkat kesulitan tinggi, namun hanya satu kelompok yang diberi peta pikiran, menunjukkan tingkat pemahaman lebih tinggi pada kelompok itu

Peta pikiran yang diadakan pada tahap prabaca dapat membantu siswa untuk memfokuskan perhatiannya pada informasi-informasi yang ditargetkan oleh pertanyaan itu selama membaca. Misalnya sebelum pelaksanaan tahap inti membaca teks tentang "dinosaurus", diadakan perumusan pertanyaan "bagaimana dinosaurus punah", "mengapa kerangkanya 
banyak ditemukan di wilayah kutub utara", sehingga siswa memberi perhatian lebih banyak terhadap materi yang berkaitan dengan pertanyaan tersebut. Ini sesuai dengan hasil penelitian Wright dan Kendall (Thalheimer, 2003:10) yang menemukan bahwa pembuatan peta pikiran dapat meningkatkan hasil belajar membaca yang dicapai siswa antara 15 hingga $20 \%$. Adapun kajian Devine (1993) menemukan peta pikiran yang diadakan dalam pembelajaran membaca teks yang sulit, menghasilkan peningkatan hasil belajar membaca. Bahkan, Bangert-Drowns, Kulik, \& Morgan (1991) menemukan pembuatan peta pikiran dapat meningkatkan hasil belajar membaca hingga 40\%. eksperimen Rickards (1976) menemukan bahwa peta pikiran yang bersifat umum dan difokuskan pada informasi yang benar-benar penting atau utama secara signifikan dapat mengembangkan pemahaman siswa

Pembuatan Peta Pikiran merupakan Upaya Melatih Siswa Berpikir Kritis

Pembiasaan membuat peta pikiran dari hasil membaca sekilas memungkinkan siswa untuk melakukan aktivitas membaca dalam keadaan siap, yakni menemukan jawaban dari peta pikiran. Dengan demikian, siswa dikondisikan untuk selalu berpikir, baik sebelum (aktivitas pikiran untuk membuat peta pikiran) maupun selama melakukan aktivitas yang sesungguhnya (aktivasi pikiran untuk menemukan jawaban terhadap pertanyaan). Hal ini dapat dikaitkan dengan penelitian Watts \& Anderson (2001) yang menemukan bahwa dengan dirumuskannya peta pikiran oleh siswa, ternyata respon yang baik tidak hanya diberikan siswa terhadap pertanyaan-pertanyaan yang menjadi peta pikiran, tetapi juga pada pertanyaan lain. Oleh karenanya, sudah saatnya guru memberi peluang siswa untuk mengembangkan kemampuan membacanya dengan berbagai strategi membaca. Ini dapat dikaitkan dengan temuan Fang (2010) bahwa siswa sekolah menengah menggunakan stratregi yang sama pada jenis teks yang berbeda dan ini mengindikasikan mereka tidak menguasai aneka ragam strategi membaca. Selain itu, sebagai suatu keterampilan, semakin sering siswa diberi kesempatan berlatih tentulah mereka akan makin terampil dalam membaca.

\section{SIMPULAN}

Dari hasil deskripsi setiap siklus maupun antarsiklus dapat dirumuskan simpulan penelitian sebagai berikut ini. Pertama, pembuatan peta pikiran pada kegiatan prabaca dapat meningkatkan keaktifan dan motivasi siswa dalam pembelajaran membaca pemahaman. Kedua, pembuatan peta pikiran dapat meningkatkan kemampuan memahami bacaan pada siswa, Ketiga, pembuatan peta pikiran dapat dilakukan secara efektif bila didasarkan dari hasil membaca sekilas isi teks, bukan membaca bagian per bagain dari teks. Bila didasarkan dari membaca per bagian teks, sementara siswa tidak memiliki informasi mengenai topik dalam bacaan secara memadai, memungkinkan yang dibuat adalah peta pikiran yang tidak menunjukkan keutuhan makna teks. Keempat, pembuatan peta pikiran yang dilakukan di bawah bimbingan guru dan atau bersama-sama teman yang setara kemampuannya memungkinkan dihasilkannya peta pikiran yang relevan dengan isi teks dan mencapai tingkat pemahaman. Mengingat pengadaan prabaca dengan peta pikiran terbukti dapat meningkatkan kemampuan memahami bacaan, peneliti mengajukan saran sebagai berikut: (1) hendaknya guru Bahasa Indonesia melakukan pembelajaran membaca dengan mengikuti proses yang benar, yaitu ada tahap prabaca, tahap membaca, dan tahap pascabaca. Selama ini prosedur membaca yang umum diterapkan adalah tanpa melalui tahap prabaca dan (2) hendaknya guru Bahasa Indonesia senantiasa menerapkan berbagai strategi pembelajaran pada tahap prabaca sehingga 
memungkinkan siswa dapat mengaktivasi pengetahuan awalnya mengenai materi

\section{REFERENSI}

Carrell, P. L. (1999). Metacognitive Awareness and Second Language Reading. Modern Language Journal, 73: 121-133.

Devine, J. (1993). "The Role of Metacognition in Second Language Reading and Writing”, Dalam Reading in the Composition Classroom, J. G. Carson \& I. Leki (Eds.), Hlm. 105-127. Boston, MA: Heinle \& Heinle.

Dole, H., Valencia, W., Greer, B., \& Waldrop, K. (1991). Effects of Two Types of Prereading Instruction on the Comprehension of Narrative and Expository Text, Dalam Reading Research Quarterly, 26: 142-159.

Eskey, D. (2002). Reading and the Teaching of L2 Reading. TESOL Journal, 11(1): 5-9.

Ferrari, Marcella \& Palladino, Paola. (2007). Foreign Language Learning Difficulties in Italian Children: Are They Associated with Other Learning Difficulties?, Dalam Journal of Learning Dissabilities, 40 (3): 256-269.

Glazer, S. M. (1992). Reading Comprehension: $\quad$ Self-monitoring Strategies to Develop Independent Readers. New York: Scholastic Professional Books.

Guthrie, J. T., Laurel, W., Stephen, M., \& Nicole, M. (2007). "Reading Motivation and Reading Comprehension Growt in the Later Elementary Years", Contemporary Educational Psychology, 32 (3): 282-313

Hartley, J., \& Davies, I.K. (2006). "Preinstructional Strategies: The Role of Pretest, Behavioral Objectives, Overviews and Advance Organizers". Review of Educational Research, 46: 239-265. bacaan, terutama melalui pembuatan peta pikiran.

Horowitz, Daniel. (1996). "Process, not Product: Less than Meets the Eye", Dalam TESOL Quarterly. 20 (1): 141- 149.

Hosenfeld, C., Arnold, V., Kirchofer, J., Laciura, J., \& Wilson, L. (2007) "Second Language Reading: A Curricular Sequence for Teaching Reading Strategies", Dalam Foreign Language Annuals, 14:. 415-422.

Keally, William A., Bakriwala, Darshan J., \& Sheridan, Philip B. (2003). "Counter Effects between an Adjunct Map and Prequestions", Dalam Educational Technology Research and Development, 51 (2):. $112-123$

Readence, J. E., Moore, D. W. \& Rickelman, R. J. (2000) Prereading Activities for Content Area Reading and Learning (Third Edition), International Reading Association, Inc.

Richards, Jack C. \& Rodgers, Theodore S. (1993). Approachs and Methods in Language Teaching. Cambridge: Cambridge University Press.

Silberstein, S. (1994). Techniques and Resources in Teaching Reading. New York: Oxford University Press.

Solan, Harold A., Shelley-Trembay, John F., Hansen, Peter C., \&Larson, Peter. (2007). "Is there a Common Linkage among Reading Comprehension, Visual Attention, and Cognitive Processing?", Dalam Journal of Learning Dissabilities, 40 (3): 270-278.

Swaffar, J., Arens, K., \& Byrnes, H. (1991). Reading for Meaning: An Integrated Approach to Language Learning. Englewood Cliffs, NJ: Prentice-Hall.

Tierney, R.J. \& Cunningham, J.W. (1984). "Research on Teaching Reading 
Comprehension", Dalam Handbook of Reading Research. P.D. Pearson (Ed.) Hlm. 609 - 655. New York: Longman.

Tompkins, Gail E. \& Hoskisson, Kenneth.(1995). Language arts:

Content and teaching strategies. Englewood Cliffis, New Jersy: Prentice-Hall, Inc.

Urquhart, A. H., \& Weir, C. (1998).

Reading in a Second Language:

Process, Product, and Practice.

New York: Longman.

White, R.E. (1981). "The Effects of Organizational Themes and Adjunct Placements on Childrens' Prose Learning: A Developmental Perspective (Doctoral Dissertation, Northwestern University). Dissertation Abstracts International, Vol. 42, 2042A-2043A. (University Micorfilms No. 81-25,038). 